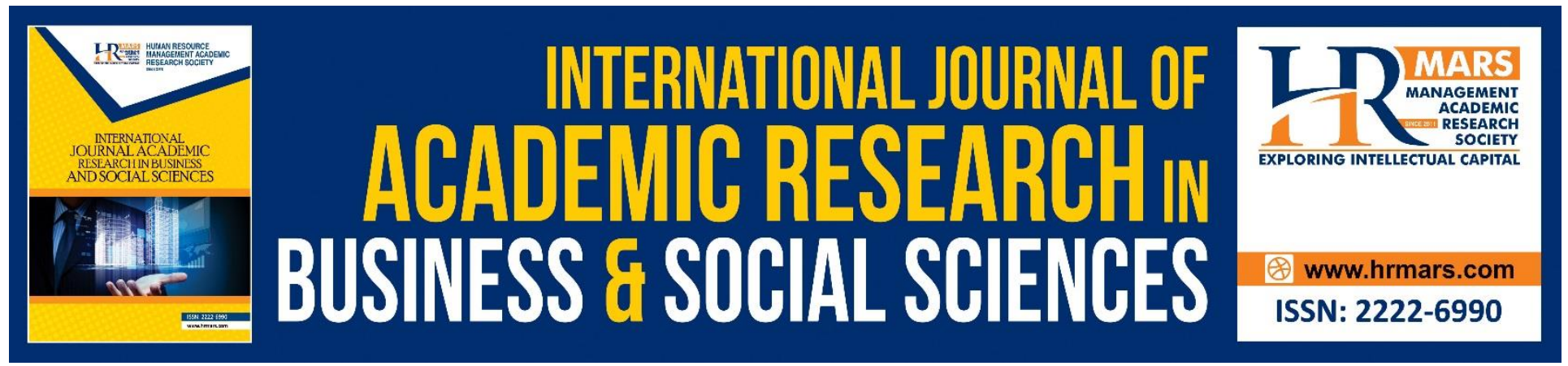

\title{
Islamic Green Practices as Catalyst for Islamic Sustainable Development in the Industrial Revolution 4.0
}

Fadzila Azni Ahmad, Wan Norhaniza Wan Hasan, Norazilawati Md Dahlal

To Link this Article: http://dx.doi.org/10.6007/IJARBSS/v8-i11/4997

DOI: $10.6007 /$ IJARBSS/v8-i11/4997

Received: 07 Oct 2018, Revised: 12 Nov 2018, Accepted: 21 Nov 2018

Published Online: 06 Dec 2018

In-Text Citation: (Ahmad, Hasan, \& Dahlal, 2018)

To Cite this Article: Ahmad, F. A., Hasan, W. N. W., \& Dahlal, N. M. (2018). Islamic Green Practices as Catalyst for Islamic Sustainable Development in the Industrial Revolution 4.0. International Journal of Academic Research in Business and Social Sciences, 8(11), 1122-1133.

Copyright: (C) 2018 The Author(s)

Published by Human Resource Management Academic Research Society (www.hrmars.com)

This article is published under the Creative Commons Attribution (CC BY 4.0) license. Anyone may reproduce, distribute, translate and create derivative works of this article (for both commercial and non-commercial purposes), subject to full attribution to the original publication and authors. The full terms of this license may be seen at: http://creativecommons.org/licences/by/4.0/legalcode

Vol. 8, No. 11, 2018, Pg. 1122 - 1133

http://hrmars.com/index.php/pages/detail/IJARBSS

JOURNAL HOMEPAGE

Full Terms \& Conditions of access and use can be found at http://hrmars.com/index.php/pages/detail/publication-ethics 


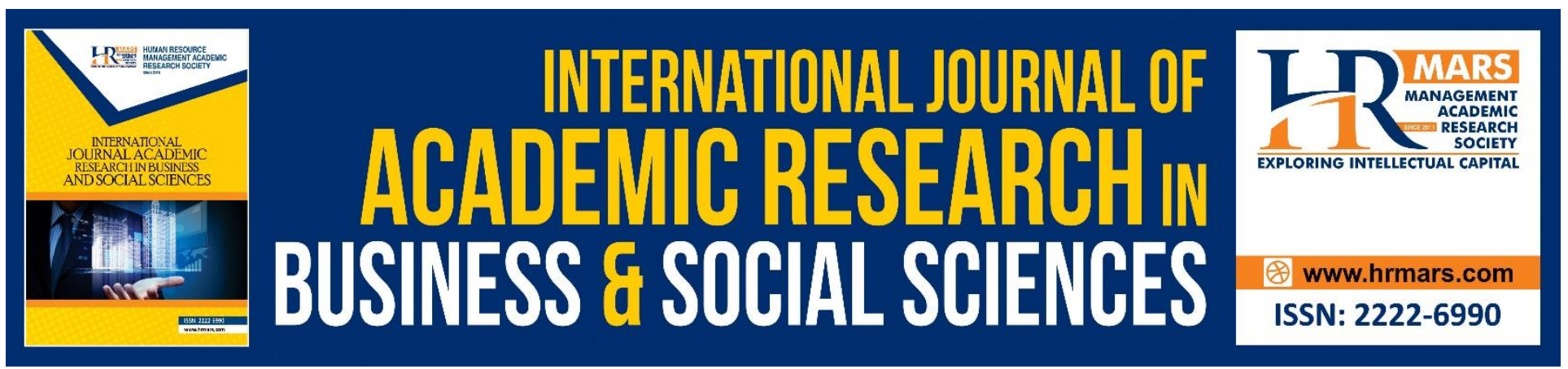

\title{
Islamic Green Practices as Catalyst for Islamic Sustainable Development in the Industrial Revolution 4.0
}

\author{
Fadzila Azni Ahmad", a, Wan Norhaniza Wan Hasan ${ }^{1, b}$, Norazilawati \\ Md Dahlal ${ }^{1, c}$ \\ ${ }^{1}$ Centre for Islamic Development Management Studies, Universiti Sains Malaysia \\ Email: asukainah@usm.my, bwanhaniza@usm.my, bwanhaniza@usm.my
}

\begin{abstract}
The latest progress in global development has seen all aspects of development aimed at the fourth level of the industrial revolution or better known as Industrial Revolution 4.0. However, in the excitement to see the potential of global and national industries expand in line with the emergence of Industrial Revolution 4.0, there arises two questions, such as what would happen to the objectives of sustainable development, which is also the aim of many other parties all this while. Could it be achieved in line with the objective of extensive involvement in Industrial Revolution 4.0? This article tried to adduce the presumption that Industrial Revolution 4.0 must consider issues related to sustainable development so that achieving Industrial Revolution 4.0 does not jeopardise the longterm harmony of the world's population. Since Malaysia is a Muslim majority country and Muslims are projected to form the majority of this earth's population in 5 decades' time; hence, discussions in this paper focused on Islamic sustainable development in Industrial Revolution 4.0. As an exploratory stage, the discussions in this study focused on the element of Islamic sustainable development, namely Islamic green practices, which could become a catalyst and activating agent in unifying and elaborating the contradictions between Islamic sustainable development and Industrial Revolution 4.0. For this purpose, the document study and qualitative content analysis methods were used.
\end{abstract}

Keywords: Islamic sustainable development, Islamic green practices, Industrial Revolution 4.0, Sustainability.

\section{Introduction}

Sustainable development is said to be a solution for the development crises being faced by almost the whole world. Initiated as an effort to preserve the environment, sustainable development later emerges to fulfill societal well-being then economic justice and now become the main agenda of current world leaders through Sustainable Development Goals (SDG). Sustainable development 
refers to development that considers every element of the ecosystem in efforts to ensure the wellbeing of humankind, including future generations. The sustainable development is also closely related to green development because of its association to environment and natural resources. The term 'green' is used to express elements of nature friendliness and responsibility towards the environment (IAAMSC, 2009). When answering the call for sustainable development, various concepts and products with a green status have emerged namely green economy, green technology and green buildings, in which all these refer to green practices or a green lifestyle.

Current trend of rapid global industrialization and technological development as well as the presence of the fourth industrial revolution or commonly called the Industrial Revolution 4.0, have witnessed the transmission era in world economics from digital systems to Cyber-Physical Systems (CPS) and the Internet of Things (IOT) (Pauzi, 2017). Previously, the industrial revolution was frequently equated with issues related to the environment. In order to achieve the aim of industrialization, the environment was manipulated to be the means of industrial input and at the same time being burden by the industrial waste. Air pollution for example, occurs due to widespread burning of fuels as a source of energy, changes in land use due to industrial factories, buildings, townships and transport facilities as well as changes in the usage of natural and human resources that were all identified as the effects of industrial revolution. This similar circumstance also caused air, land and noise pollution. All these elements have had an impact, mainly on the well-being of humankind and its surroundings. Moreover, previously, the effects of industrial revolution have had a negative impact on human well-being by creating an income gap and accessibility to facilities that were produced by the revolution.

According to the above scenario, this article analyse Islamic sustainable development as a form of solution in the Industrial Revolution 4.0 era so that contemporary developments in global technology and sustainable development as envisioned by world leaders do not hinder one another as what happened during the previous industrial revolution. The discussions were qualitative in nature using secondary data from published documents. Two main groups of documents were used. One was written documents related to sustainable development, mainly green practices for achieving the aim of sustainable development, while the other was related to the Industrial Revolution 4.0. Since this article looked at it from the Islamic perspective, the verses of the al-Qur'an and Hadith, as epistemological sources of Islamic knowledge, were utilised to ensure the concept is examined within the Islamic-based framework. Discussions in this article focused on Islamic sustainable development background, specifically green practices and the Industrial Revolution 4.0. based on these discussions, this article tried to present Islamic green practices found in Industrial Revolution 4.0 era, indicating that the aim of Islamic sustainable development could still be achieved during Industrial Revolution 4.0.

\section{THE CLASH BETWEEN SUSTAINABLE DEVELOPMENT AND INDUSTRIAL REVOLUTION 4.0}

Ecologists and population biologists use population dynamics model to discuss on carrying capacity. For them, each ecosystem has a specific carrying capacity. An increase in population exceeding the ecosystem's carrying capacity would cause an excessive use of resources and eventually 
INTERNATIONAL JOURNAL OF ACADEMIC RESEARCH IN BUSINESS AND SOCIAL SCIENCES Vol. 8, No. 11, Nov, 2018, E-ISSN: 2222-6990 (C) 2018 HRMARS

cause a collapse in population growth. This view was also debated among economists and develop scholars and the outcome of it was in the form of a report, published under The Limits to Growth by the Club of Rome. The report showed that presumptions about the design of the economic growth and world population occurred exponentially while natural resources are in a limited and restricted mode (Meadows et al., 1972). Rapid industrialization and technological development that had contributed to population growth and consumption of natural resources is seen as a threat to natural surroundings. As for environmental scholars and lovers, rapid economic growth and development after the first industrial revolution in 1800s had triggered various problems, especially those that had affected the natural surroundings. Hence, due to this crisis, focus on sustainable development had increased resulting in numerous conferences, reports and protocols adduced to discuss various aspects of the ecological crises that emerged due to rapid development occurring all over the world.

The thrust of sustainable development currently emerged during the United Nations Conference on Human Environment in 1972. The conference had discussed concerns that human actions that threaten earth's environment could be irreversible and this could then threaten future generations of humankind. Consequently, awareness rose about sustainable development without only focusing on economic and social sectors but also considering the use of natural resources and its impact on the environment. Since the conference, various initiatives have been implemented to ensure successful sustainable development. Among the initiatives implemented were the Brundtland Report entitled "Our Common Future", which talked about apprehensions, challenges and endeavours to achieve sustainable development (WCED, 1987). The next initiative was the Rio de Janeiro Earth Summit held in 1992 (Bell \& Morse, 2008). Until now, sustainable development has been the focus of the whole world, such as the main agenda in development, specifically through Agenda 2030 for Sustainable Development that contains SDG.

Although exasperated with the danger posed to the environment due to development, humankind has the capability to create technology and produce new resources to ensure development and continued growth. Unfortunately, this optimistic trust forms a cycle of destruction because new technologies and sources of energy culminating from various industrial revolutions have been empirically proven to cause destruction and pollution. In order to overcome this problem, new technology has been continuously created, which then brings new forms of destruction to other aspects of life. Hence, sustainable development is further explored and studied to enable humans to live in harmony and development to carry on smoothly and progressively

The industry is part of the economic elements that produce products and services that are very mechanistic and automated. Since the beginning of the industrial era, developments in science and technology have brought about a significant paradigm change, which was eventually referred to as the "industrial revolution". Developments in science and technology are usually referred to the start in using water and steam power for the mechanization process (the first industrial revolution), use of intensive electrical energy (the second industrial revolution) and widespread digital changes (the third industrial revolution) (Lasi et al., 2014). 
INTERNATIONAL JOURNAL OF ACADEMIC RESEARCH IN BUSINESS AND SOCIAL SCIENCES Vol. 8, No. 11, Nov, 2018, E-ISSN: 2222-6990 @ 2018 HRMARS

Lately, a paradigm shift had occurred in the manufacturing industry and it was referred to as Industrial Revolution 4.0, which was basically characterised according to smart factories, smart products and smart services based on the Internet of Things (IOT) and the industrialisation of the internet. Developments in Industrial Revolution 4.0 have provided great opportunities for the development in ICT infrastructure, which has been growing in popularity.

From one aspect, Industrial Revolution 4.0 is one of the methods used to achieve sustainable development by providing various technologies and facilities in order for the world's society to access various opportunities. Hence, by using this method, the issue of limitations due to the geographical gap could be overcome and solved. For example, society in a specific geographical location could access information from another location in real-time without having to face delays. The dissemination of knowledge would be made easier and Industrial Revolution 4.0 would open avenues for real-time global communication.

Hence, it is appropriate that Industrial Revolution 4.0 receives attention and is thoroughly explored. Although this revolution would eventually cause anxiety among advocates of sustainable development, however, Industrial Revolution 4.0 itself is capable of becoming a tool for achieving sustainable development. In accordance with rapid growth in the world's Muslim population, Islamic sustainable development is one form of development that could be the best option for implementation.

\section{ISLAMIC SUSTAINABLE DEVELOPMENT AND ISLAMIC GREEN PRACTICES}

Previous discussions have shown a close relationship between sustainable development, preservation and conservation of natural surroundings. Besides that, sustainable development is also closely related to human well-being and an expanding economy. Just as sustainable development prioritises development in a situation where all aspects of the ecosystem are preserved, Islamic sustainable development also believes in such a position. A stark difference between sustainable development and Islamic sustainable development lies in the epistemology of both these developments. Sustainable development that is deductive and formed in a reactive manner is the result of empirical experiences caused by the previous industrial revolution. Meanwhile, Islamic sustainable development, although not mentioned or referred to as Islamic sustainable development, had come into existence due to the exhortation by Allah SWT found in the al-Qur'an or the sunnah of the Prophet SAW. Therefore, the epistemology of Islamic sustainable development itself is proactive in nature and formed inductively.

One of the sources that had indicated about Islamic sustainable development was the exhortation by Allah SWT, meaning:

"And He it is who causes gardens to grow, [both] trellised and untrellised, and palm trees and crops of different [kinds of] food and olives and pomegranates, similar and dissimilar. Eat of [each of] its fruit when it yields and give its due [zakah] on the day of its harvest. And be not excessive. Indeed, He does not like those who commit excess" 
(Al-An'am, 6:141)

The exhortation by Allah SWT above is a guide for humankind regarding the use of natural resources. Fruits and plant products are created by Allah SWT as s source of food for humankind. Nevertheless, this verse clearly shows that vegetation and agriculture products are not absolutely owned by humans. On the contrary, humankind has two main responsibilities, which is to distribute these products through zakat and not to use it excessively and extensively or wastefully (Hamka, 1982:74). According to Al-Maraghiy (2001:2044), excessive prohibitions that transgress the use of natural resources can be divided into two main elements. First, excessiveness that transgresses the parameters of halal and haram stipulated by Allah SWT. Second, excessiveness that leads to beyond normal human needs would invite harm.

The exhortation by Allah SWT shows that the source for implementing sustainable development comprises natural surroundings, which is unlimited in nature and created by Allah SWT right from the beginning until to this day. However, the use of this source is dependent on regulations stipulated by Allah SWT, which is not to go overboard by following one's basic instinct (nafsu) so much so that it leads to deleterious effects, as exhorted by Allah SWT as follows:

"But seek, through that which Allah has given you, the home of the Hereafter; and [yet], do not forget your share of the world. And do good as Allah has done good to you. And desire not corruption in the land. Indeed, Allah does not like corrupters."

(Al-Qasas, 28:77)

Al-Jayyousi (2012) adduced four principles that should be implemented in order to achieve Islamic sustainable development, which were justice (keadilan), benevolence (ehsan), love (kasih saying) and the eradication of what is forbidden. In reference to these four principles, he was of the opinion that the implementation of desired development is not only just and inclusive to humans but also to natural resources, which are the creations of Allah SWT. Nevertheless, all four principles only function effectively if all sectors, as in the government, industry and society, come together to implement it. In this way, Islamic sustainable development could be realised.

Commitment towards Islamic sustainable development among leaders of Islamic nations is reflected in the existence of the Islamic Declaration for Sustainable Development, which was lately ratified in 2012. This declaration was pursuant to the earlier declaration in 2002, which again emphasised the views of Islamic world leaders about various aspects of prosperity found in sustainable development based on Islamic teachings. According to this declaration, Islamic world leaders had pledged to give their political commitment to implement development based on a green economy that is just and comprehensive for all strata of society and the preservation of natural surroundings. This commitment is achieved by empowering institutional frameworks, eradicating poverty, introducing food and agriculture security, disaster management, clean water and efficient energy. 
As for the general public, one of the methods to achieve Islamic sustainable development is Islamic green practices. Green practices can be defined as any form of activity that involves development and application of products, campaigns, policies, equipment as well as systems to preserve natural surroundings and environments as well as minimise or alleviate the negative effects of human activities as mention by Ministry of Energy, Green Technology and Water. Based on this definition, the parallelism between green practices and the support in achieving sustainable development is evident. Manakotla and Jauhari (2007) had defined 'Green' as being nature friendly and responsible for the environmental. In addition, Divine and Lepisto (2005) termed green practices as a green lifestyle.

Therefore, it could be understood that green practices are activities or things that are nature friendly or reflects the responsibility of people on this earth to the natural environment. Among examples of green activities are the practice of re-cycling, consuming organic food, buying green products etc.

Green practices first received attention when an increasing number of parties began taking notice of the fact that the earth and the natural environmental cycle was being destroyed and the situation was getting increasingly critical. This problem originated from continuous development and lack of perseveration activities by humans who had been aggressive in carrying out development activities that caused the rate of destruction of nature to increase year by year. Hence, green practices not only became the focus but the commitment to implement it was also emphasised during international discourses. One example was Malaysia's commitment during the Conference on Climate Change in Copenhagen in 2010, which aimed at a 40\% decrease in carbon emissions by 2020.

In order to realise this commitment, the Malaysian government, under the auspices of the Ministry of Natural Resources and Environment, had undertaken the following 8 steps as an initiative towards green practices by Ministry of Natural Resources and Environment in the context of sustainable climate change:

i. Feed-In Tariff (FIT) scheme for encouraging the use of re-newable energy such as solar energy.

ii. Green Technology Financing Scheme (GTFS) for expediting the supply and use of green technology through the financing provided.

iii. The Mixing of 5\% Bio-diesel with 95\% Fossil Diesel (B5). The bio-diesel referred here is palm oil and the aim of using it was to reduce greenhouse gases (GHG) because the carbon component content in bio-diesel B5 is presumed to be carbon-neutral and can reduce GHG emissions.

iv. Green Building Index (GBI) Certification Program to encourage building and restructuring of current buildings to make them nature friendly (green buildings).

v. The use of Compressed Natural Gas (CNG) by vehicles that have lower carbon factor compared to the carbon emission factor by petrol.

vi. Use of Public Transport such as light rail transit (LRT), mass rapid transit (MRT) as well as monorail services and Hybrid vehicles. 
INTERNATIONAL JOURNAL OF ACADEMIC RESEARCH IN BUSINESS AND SOCIAL SCIENCES Vol. 8, No. 11, Nov, 2018, E-ISSN: 2222-6990 @ 2018 HRMARS

vii. The Sustainability Achieved via Energy Efficiency (SAVE) Program for oil, gas and energy sectors.

viii. The "Greening the Planet: One Person, One Tree" Campaign that was launched simultaneously all over the world in conjunction with the World Earth Day Celebrations on 22 April 2010. Until the end of 2013, some 53 million trees have been planted over an area of 65,560 hectares all over Malaysia.

From an Islamic perspective, the important basis of green practices is evident in the policies found in Islamic tasawur (worldview) that puts natural surroundings as a creation of Allah SWT, which was bestowed onto humans as a form of endowment to be managed well. It is also in accordance with the duties and status bestowed by Allah SWT to humans as a khalifah in order to manage nature and at the same time be grateful for a prosperous and harmonious natural surrounding as humans are HIS subjects. In relation to this, the verses of the al-Qur'an and the Hadith can be basic guidelines on how green practices can be realised.

"Corruption has appeared throughout the land and sea by [reason of] what the hands of people have earned so He may let them taste part of [the consequence of] what they have done that perhaps they will return [to righteousness].

(Surah al-Rum 30:41)

This verse from the al-Qur'an states that destruction of natural surroundings originates from humankind or their own activities. On the contrary, humankind can also endeavour to ensure that destruction of nature does not occur by implementing certain activities such as green practices. Next is the guideline based on the Hadith.

"If, however when Doomsday is about to arrive and in the hands of someone among you there is a date (kurma) seed, hence, when that person is able to plant the seed before Doomsday arrives then that person should plant it."

(Hadith Narrated by Imam Ahmad 3/183, 184, 191, Imam Bukhari in the scripture AlAdab Al-Mufrad no. 479 and Ibnul Arabi in his scripture Al-Mu'jam 1/21 from the Hadith by Hisyam bin Yazid from Anas r.a.).

This Hadith also elaborates on the priority of ensuring the sustainability of natural surroundings and implementing green practices no matter what the barriers. Generally, green practices include implementing activities or things that are nature friendly or those that portray the responsibility towards natural surroundings as stipulated in Islam. Hence, the basis for implementing green practices must follow the fundamentals of Islamic philosophy, which is the adherence to the tauhid of Allah SWT as the Creator of the Universe and all of humankind. The implementation of green practices needs to adhere to both the vertical dimension, which is the relationship between humankind and Allah SWT (hablumminallah) and the horizontal dimensions pertaining to the intra-humankind relationship as well as between humankind and the natural surroundings (hablumminannas). The vertical relationship in the context of implementing green practices is when humankind implements 
green practices as a form of obedience to the Creator as well as the implementation of a khalifah's duties borne by humankind. Meanwhile, the horizontal relationship involves humans who always consider their responsibility towards other humans as well as the natural surroundings that far outweighs their self-importance. Moreover, the final aim of implementing green practices should move towards obtaining the blessings of Allah SWT (mardhatillah) (Salleh, 2002).

In order to realise green practices based on Islamic philosophy, each human should begin by implementing three practices outlined according to the nas or verses from the al-Qur'an and Hadith. Following is the interpretation of the verses of the al-Qur'an and the Hadith, meaning:

".... Indeed, the wasteful are brothers of the devils, and ever has Satan been to his Lord ungrateful."

(Surah al-Israa, 17: 27)

"O children of Adam, take your adornment at every masjid, and eat and drink, but be not excessive. Indeed, He likes not those who commit excess"

(Surah al-A'raf, 7:31)

"If, however when Doomsday is about to arrive and in the hands of someone among you there is a date (kurma) seed, hence, when that person is able to plant the seed before Doomsday arrives then that person should plant it."

(Hadith Narrated by Imam Ahmad 3/183, 184, 191, Imam Bukhari in the scripture Al-Adab Al-Mufrad no. 479 and Ibnul Arabi in his scripture Al-Mu'jam 1/21 from the Hadith by Hisyam bin Yazid from Anas r.a.).

In the first nas or verse from the al-Qur'an, the guideline pertaining to the implementation of Islamic-based green practices by using, producing or through activities, forbids wastage. According to Hasan (2002), the prohibition on wastage includes going overboard in using products as well as not stocking or saving property or income. Hence, in the context of Industrial Revolution 4.0, although mass production occurs due to sophisticated and efficient technology, however, the production must consider avoiding or minimising wastage. Currently, there are innumerable issues related to the problem of wastage. For example, food remains that are thrown away due to unnecessary wastage would rot and eventually produce greenhouse gases, such as methane and carbon dioxide, leading to global warming and ending in a natural disaster. Besides that, waste material from these wastages would cause smell, river, sea pollution. This would potentially jeopardise the existence of other fauna as well and all these would be due to wastage.

The next nas or verse from the al-Qur'an emphasises on practices that are not excessive or those that instil a sense of moderation in order to encounter wastage. Hence, green practices are very important in ensuring that sustainability is achieved when facing Industrial Revolution 4.0 by always practicing a moderate attitude in production activities, consumption etc. For example, although the phase prior to Industrial Revolution 4.0 involved various smart equipment, moderation must be the 
priority, especially in the context involving related smart equipment. One worrying issue currently is the over exposure to smart technology and equipment without considering practices that are moderate so much so that it causes various issues, such as concerns on human health and social wellbeing.

The next nas based on the Hadith outlines another green practice that is of great need and easy to implement by any individual, which is to always green nature with plants and vegetation. The analogy posed by this hadith is that if the world is leading to chaos, then greening the world by planting vegetation would still be a priority according to Islam. In line with this, if vegetation or trees are destroyed or cut-down in the name of Industrial Revolution, it should be replaced more aggressively by re-planting trees or vegetation considering the time it takes for the trees to grow.

The implementation of Islamic-based green practices as discussed above is shown in Diagram 1 as follows:

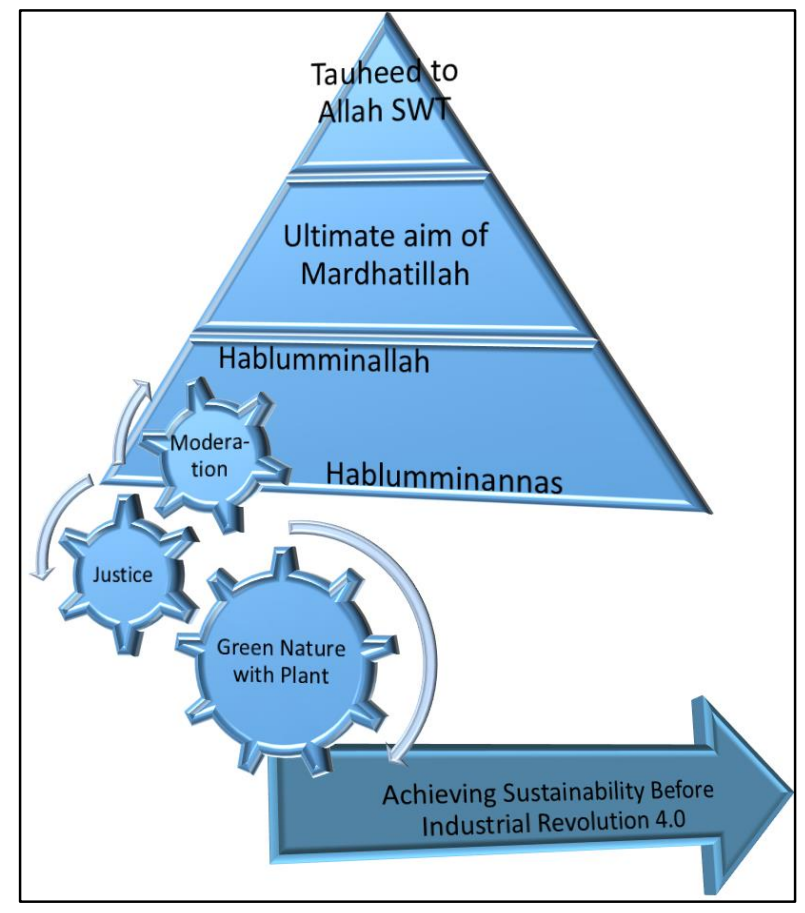

Figure 1: Achieving Sustainability Elucidates the Industrial Revolution Phase Through Islamic Based Green Practices

Thus, if at least three of the practices outlined according to the al-Qur'an and Hadith are implemented, then Industrial Revolution 4.0 would not contradict the achievements of sustainable development.

\section{CONCLUSION}


Studies have found the existence of a merger between sustainability and Industrial Revolution 4.0, with a condition that green practices should at least be emphasised. Hence, even though there exist elements of contradiction between both due to the characteristics of sustainable development that prioritises preservation of nature, the characteristics of Industrial Revolution that enhance production and consumption by using various technologies act as a shortcut. This situation could be combined by ensuring that at least the manifestation of humankind's obedience to the Allah SWT through the implementation of Islamic-based green practices is realised. Green practices at the individual level that could expand to the societal, national as well as international levels could ensure that the Industrial Revolution does not violate the sustainability of nature and negate the aim of sustainable development. Although there are contradictions between sustainable development and Industrial Revolution 4.0, hence, it is undeniable that both contribute towards human development as well as preserve nature. This finding, as a result of this early exploratory study, shows the relationship between Industrial Revolution 4.0 and sustainable development. It is suggested that future studies should involve a more shystematic data collection method in order to provide a more optimum and conducive relationship and impact for the good of humankind and nature.

\section{ACKNOWLEDGEMENT}

Special thanks to Universiti Sains Malaysia for making it possible for this paper to be written. This paper is part of the research entitled Halal-Green $\left(\mathrm{H}^{2}\right)$ Management Model (203/CISDEV/6711527) and conducted with assistance from the Fundamental Research Grant Scheme (FRGS) [FRGS/1/2015/SS03/USM/02/4] initiated by the Ministry of Higher Education Malaysia.

\section{REFERENCES}

Al-Hafiz, A M. (2011). Sejarah lengkap Nabi dan Rasul dalam Al-Quran Al-Karim. Selangor: Al-Hidayah Publications.

Al-Jayyousi, O. R. (2012). Islam and sustainable development: New worldviews. England: Gower Publishing Limited.

Karam, A. (2014). Religion and Development Post-2015: Report of a Consultation among Donor Organizations, United Nations Development Agencies and Faith-Based Organizations. New York: UNFPA.

Divine, R. L. \& Lepisto, L. (2005) "Analysis of the healthy lifestyle consumer", Journal of Consumer Marketing, Vol. 22 Issue: 5, pp.275-283, https://doi.org/10.1108/07363760510611707

García, L. E. (2011). Sustainable Development and the Private Sector: A Financial Institution Perspective. dlm. Bridges to Sustainability. Diakses dari http://environment.yale.edu/publicationseries/documents/downloads/0-9/101garcia.pdf

IAAMSC (2009). Glossary of green terms and definition. Diakses dari https://www.iavm.org/sites/default/files/documents/Green_Glossary_of_Terms _and_Definitions_for_International_Association_of_Assembly_Managers_final.pdf 
INTERNATIONAL JOURNAL OF ACADEMIC RESEARCH IN BUSINESS AND SOCIAL SCIENCES Vol. 8, No. 11, Nov, 2018, E-ISSN: 2222-6990 C 2018 HRMARS

Pauzi, M.M. (2017). Revolusi Perindustrian 4.0: Satu Pengenalan. Diakses daripada https://www.scribd.com/document/363699423/06-Revolusi-Industri-4-0 pada 13 Januari 2018.

Manakotla, K., \& Jauhari, V. (2007). Exploring consumer attitude and behavior towards green practices in the lodging industry in India. International Journal of Contemporary Hospitality Management, 19 (5), 364-377. http://dx.doi.org/10.1108/09596110710757534

Al-Baqi, M.F.A. (1364H). AlMu'jam alMufahras li alfazh al Quran al Karim. Diakses dari https://archive.org/details/AIMujamAIMufahrasLiAlfazhAlQuran

Salleh, M.S. (2002). Pembangunan Berteraskan Islam. Kuala Lumpur: Utusan Publications and Distributors Sdn. Bhd.

National Research Council. (2010). The Impact of Genetically Engineered Crops on Farm Sustainability in the United States. Washington, D.C.: National Academies Press.

Sharma, S. \& Gandhi, M.A (2016). Exploring correlations in components of green supply chain practices and green chain performance. Competitiveness Review, 26(3), 332-368. doi: org/10.1108/CR-04-2015-0027

Hasan, S.K. (2002). ). Perbelanjaan bermanfaat dan tidak membazir menurut perspektif Islam. Jurnal Syariah. 10(2). 87-98.

Bahaldin, S.A.S. (2005). Alternative quality management standards: Islamic perspectives. Kuala Lumpur: Utusan Publications \& Distributors Sdn Bhd

UN (United Nations). (2015). UN forum highlights 'fundamental' role of private sector in advancing new global goals. Dlm. News, Sustainable Development Agenda. http://www.un.org/sustainabledevelopment/blog/2015/09/un-forum-highlights-fundamental-roleof-private-sector-in-advancing-new-global-goals/

UN (United Nations). (2016). Global Sustainable Development Report 2016. New York: Department of Economic and Social Affairs.

World Bank. (2015). Global conference on religion and sustainable development: Strengthening partnership to end extreme poverty. News: Press release. 12 July 2015. http://www.worldbank.org/en/news/press-release/2015/07/12/global-conference-religionsustainable-development 